\title{
Usporedba načina pisanja o književnosti književnih kritičara i neprofesionalnih čitatelja-blogera
}

\section{Abstract: Comparative Research of the Ways Professional Readers and Unprofessional Readers-Bloggers Write about Literature}

The purpose of this paper is to compare the ways professional and unprofessional readers write about literature. The analyzed corpora will consist of three blogs dedicated to literature (the unprofessional, $\mathrm{N}$ corpus) and book reviews published in two professional publications (the professional, P corpus). The criteria for choosing the texts that would enter the corpora were a relatively solid readership and the same publication period. By using digital tools such as Sketch Engine and MAXQDA 2020, the following data was analyzed: the titles and authors mentioned, most frequent words and most frequent multi-word terms. Based on these macro-level results, a few texts were chosen for a deeper, sentence-level analysis. The results were compared to similar research regarding unprofessional readers.

Keywords: professional readers, unprofessional readers, reader reception, book blogs, digital humanities

\section{Uvod}

Digitalna revolucija utjecala je ne samo na sam medij književnosti, već i na način govora i informiranja o književnosti, za što je posebno značajna pojava Weba 2.0. Različiti autori naglašavaju prednosti odnosno nedostatke alata koji internetskim korisnicima omogućuju stvaranje 
vlastitog sadržaja. Steiner ističe kako zahvaljujući internetu čitatelji više nisu tek pasivni primatelji i konzumenti, već javno i aktivno iznose svoje mišljenje o pročitanome, potiču polemike te naposljetku utječu i na popularnost određenih književnih djela $(476,481)$. Ovo je važno posebno u kontekstu neprofesionalnih čitatelja, čiji se glasovi često reduciraju ili isključuju iz institucionalne književnosti (Škopljanac 242). Urednici internetskih stranica također imaju mogućnost kontrole glasova neprofesionalnih čitatelja, prije svega manipuliranjem vidljivošću njihovih komentara. Primjerice, Walsh i Antoniak opisali su na koji način algoritmi stranice Goodreads kontroliraju vidljivost komentara, zbog čega je za svaku knjigu moguće pročitati njih maksimalno 300, a što je zapravo tek mali postotak svih postojećih komentara. Za razliku od stranica poput Goodreadsa, blog najčešće piše i uređuje jedna osoba (Steiner 480), što i odgovara njegovu formatu svojevrsnog osobnog dnevnika.

Unatoč tome što i sam ističe demokratizaciju odnosa autora i čitatelja kao odliku sveopće digitalizacije, Adriaan van der Weel kritički je nastrojen prema ovoj pojavi te objašnjava kako digitalni prostor nema nikakvih kriterija kvalitete, doprinosi gubljenju autoriteta i prestiža autorstva, olakšava aproprijaciju tuđih sadržaja te briše granicu između privatnog i javnog, budući da se objavljuju mnogi sadržaji koji bi inače pripadali isključivo privatnoj sferi. Budući da je polje interneta izuzetno dinamično, tekstovi na društvenim mrežama, blogovima i fanfiction stranicama brzo se izmjenjuju te zbog toga često nisu pisani posebno precizno niti su stilski razrađeni (van der Weel 230).

Digitalizacija mijenja i nakladničku industriju, pa se javljaju novi oblici samoizdavaštva i novi marketinški pristupi, te glasovi i mišljenja neprofesionalnih čitatelja dobivaju sve veći komercijalni potencijal. Prema Steiner, neprofesionalni književni blogovi važan su dio nakladničke industrije jer zbog intenzivnog tempa izdavanja knjiga na globalnoj razini dolazi do „poplave” novih naslova, u kojoj se potencijalni čitatelji pokušavaju orijentirati na različite načine, između ostalog, čitajući recenzije na književnim blogovima (481-482). Stoga nakladnici redovito nastoje ostvariti suradnju s čitanijim blogerima te im šalju recenzentske primjerke knjiga, a takva praksa česta je i u Hrvatskoj. Steiner je istraživala neprofesionalne književne blogove u Švedskoj te je zapazila sljedeće: autorice su u velikoj većini žene, tekstovi su uglavnom kratki i često su neuređeni, blogeri povezuju osobna iskustva s pročitanim djelima, pišu o najrazličitijim žanrovima (o mnogima bi se teško 
mogle naći profesionalne recenzije) te često opisuju sam fizički kontakt s knjigom (kupovina, vanjski izgled, dodirivanje, miris), kao i vlastito iskustvo čitanja. Na prigovore kako književni blogovi promiču amaterstvo i predstavljaju prijetnju profesionalnom kritičaru, Steiner odgovara kako su načini selekcije, kanonizacije i općenito moć književnih kritičara već mnogo puta dovođeni u pitanje (486). Osim toga, blogere se kritizira i zbog podložnosti marketingu i nakladničkim trendovima, a Steiner ističe kako ni profesionalni kritičari nisu imuni na mehanizme samopromocije i marketinga jer su na različite načine povezani s književnim poljem i u određenom su odnosu s njegovim akterima (486). Neki blogeri, ističe Steiner, ne populariziraju samo određene naslove, već i čitanje općenito, te govore o književnosti na nove i inovativne načine, čime mogu poslužiti kao inspiracija profesionalcima $(483,485)$.

S druge strane, Horvat, Ljevak, Tomašević i Gavranović ističu problem spektakularizacije i estradizacije književne kritike te sve manjeg medijskog prostora za profesionalnu književnu kritiku, koju potencijalno istiskuje utjecaj stajališta „kritičara amatera”. Autorice primjećuju digitalnu uvjetovanost javne sfere govora o knjizi, a u toj (digitalnoj) javnoj sferi o njoj govore nakladnici putem nakladničke anotacije, knjižnice putem knjižničarske anotacije, biltena i sl., eksperti, što su književni kritičari, te neeksperti putem komunikacijskih kanala novih medija (Horvat et al. 78). Ovaj rad fokusirat će se na usporedbu govora o književnosti onih koje su autorice nazvale ekspertima, odnosno profesionalnih književnih kritičara, te neekspertima, odnosno književnih blogera, pritom koristeći metode digitalne humanistike i analize primjera. Čitanje na različitim razinama, od udaljenog prema primjerima na razini rečenice, otkriva nove fenomene zbog promjene perspektive, a kvantitativni podaci udaljenog čitanja mogu uputiti na dijelove korpusa koji bi bili korisni za detaljnu analizu i razumijevanje načina na koji opći uzorci proizlaze iz individualnih pojava (Pianzola, Rebora i Lauer).

\section{Definiranje korpusa i potkorpusa}

Radi usporedbe načina pisanja o književnosti profesionalnih i neprofesionalnih čitatelja odabrana su tri književna bloga, jedan internetski portal na kojem se objavljuju profesionalne književne kritike (Moderna vremena info: mvinfo.hr) te digitalizirane verzije tiskane publikacije Vijenac (dostupne besplatno online na: matica.hr/vijenac), koja također sadrži profesionalne književne kritike. 
Recenzije objavljene na blogovima predstavljaju korpus pisanja o književnosti neprofesionalnih čitatelja (korpus N), točnije čitateljica, jer su autorice sva tri analizirana bloga žene, kao i kod većine književnih blogova, što je u svom istraživanju zapazila i Steiner (477). Recenzije objavljene na mvinfo.hr i u Vijencu čine korpus pisanja različitih profesionalnih književnih kritičara i kritičarki (korpus P). Glavni kriterij za odabir potkorpusa bili su podjednak konačan broj riječi u korpusu N i korpusu P te podjednak vremenski raspon objavljenih recenzija. Vijenac i mvinfo.hr odabrani su jer su njihovi sadržaji digital(izira)ni i dostupni online. Također, analizom su obuhvaćeni i podaci o posjećenosti internetskih stranica te broj pratitelja blogova na popratnim profilima na društvenim mrežama. Pretpostavka je da su blogovi s relativno većim brojem pratitelja popularniji i utjecajniji u određenom krugu neprofesionalnih čitatelja.

Kao posljednja koja je ušla u korpus iz svih pet potkorpusa uzeta je recenzija objavljena prije 20. svibnja 2021. Prva recenzija na blogu Čitateljica objavljena je 1. kolovoza 2018., na blogu Knjige su moj svijet 22. svibnja 2018., a na Books\&Sweets 11. studenog 2018. Svi blogovi imaju između 5 i 15 tisuća pratitelja na popratnim Facebook profilima. Budući da se navedeni blogovi sastoje gotovo isključivo od recenzija i osvrta na knjige, čitavi su prebačeni i generirani u jedan korpus u programu Sketch Engine. Ukupan broj riječi sva tri bloga, odnosno konačan broj riječi korpusa N iznosio je 353.128 riječi.

Iz Vijenca su uzete recenzije objavljivane u rubrici Književnost, od dvobroja 639 - 640 (13. rujna 2018.), zaključno s brojem 710 (20. svibnja 2021.). Na stranici mvinfo.hr obuhvaćene su sve recenzije pod rubrikom Kritike u rasponu od 11. svibnja 2018. do 4. svibnja 2021. Budući da su stranice na kojima su objavljivane profesionalne recenzije složenije, odnosno imaju više različitih sadržaja, a i kako bi se pazilo na broj riječi i vremenski raspon ${ }^{[1]}$, recenzije su, svaka zasebno, ručno prebacivane u program Sketch Engine. Ukupan broj riječi korpusa P iznosi 351.647. Što se tiče utjecaja i popularnosti, naklada Vijenca je 6000 primjeraka, 4000 ljudi bilo je pretplaćeno na njega 2019. godine, a ostali brojevi distribuirani su na kioske diljem Hrvatske (Olujić). Prema stranici websiteiq.com (pristup 7. lipnja 2021.), stranica matica.hr, na kojoj se nalazi digitalizirana arhiva Vijenca, otvorena je 19.844 puta, a stranica mvinfo.hr 37.718 puta (podaci za travanj 2021.). 
Paralelno s unosom korpusa izrađivane su liste recenziranih naslova, zajedno s imenima autora, koje su zatim poslužile za usporedbu književnih djela i pisaca zastupljenih u dva korpusa. Uslijedila je analiza najčešćih riječi u svakom korpusu, za što je, zbog različitih mogućnosti vizualnog prikazivanja podataka, odabran program MAXQDA 2020. Osim najfrekventnijih riječi, pomoću Sketch Enginea provjerene su i najčešće sintagme (Multi-word Terms) u oba korpusa. Naposljetku, na temelju dobivenih rezultata izdvojeni su tekstovi za pomno čitanje, a to su recenzije naslova koji se pojavio u najvećem broju potkorpusa te recenzije najčešće recenziranog djela jedine autorice (Margaret Atwood) koja se pojavila u svih pet potkorpusa.

\section{Naslovi i autori}

U korpusu $\mathrm{N}$ od 22. svibnja 2018. do 20. svibnja 2021. recenzirana su ukupno 424 naslova (prosječno 832 riječi po naslovu), a u korpusu $\mathrm{P}$, od 11. svibnja 2018. do istog zaključnog datuma, 296 naslova (prosječno 1188 riječi po naslovu).

Od ukupno obrađenih 700 različitih naslova, tek njih dvadeset pojavilo se u oba korpusa. Ovakav rezultat ukazuje na značajnu razliku u odabiru naslova za recenziju između profesionalnih i neprofesionalnih čitatelja. Također, u profesionalnim potkorpusima uočljiva je i određena zastupljenost poezije (tridesetak naslova) te dvadesetak publicističkih naslova, dok se lista naslova spomenutih u korpusu $\mathrm{N}$ sastoji gotovo isključivo od pripovjednih proznih tekstova, odnosno romana, što je karakteristika i drugih istraživanja neprofesionalnih čitatelja (Škopljanac 251). Nekoliko publicističkih naslova pojavljuje se i u korpusu N, međutim, za razliku od drugog korpusa, čiji su publicistički naslovi uglavnom s područja humanističkih znanosti, u blogovima se recenzirala popularna publicistika, poput priručnika o prehrani i tzv. lifestyle publicistike.

Tablica 1. prikazuje zastupljenost dvadeset zajedničkih naslova u pojedinim potkorpusima, od onih prisutnih u najvećem broju potkorpusa (4) prema onima koji se pojavljuju u minimalnom broju (2). Nijedan naslov nije recenziran u svih pet potkorpusa.Tablica 1 - Naslovi recenzirani u oba korpusa

\begin{tabular}{|l|l|l|l|l|l|}
\hline KORPUS: & N & P & & \\
\hline POTKORPUS: & $\begin{array}{l}\text { A } \\
\text { (ČITATELJICA) }\end{array}$ & $\begin{array}{l}\text { B } \\
\text { (KNJIGE SU MOJ } \\
\text { SVIJET) }\end{array}$ & $\begin{array}{l}\text { C (BOOKS\&SWEETS) } \\
\text { (MIT) }\end{array}$ & $\begin{array}{l}\text { D } \\
\text { (MVINFO) }\end{array}$ \\
\hline $\begin{array}{l}\text { Nijema pacijentica } \\
\text { Alex Michaelides: }\end{array}$ & $\mathrm{X}$ & $\mathrm{X}$ & $\mathrm{X}$ & $\begin{array}{l}\text { E } \\
\text { (VIJENAC) }\end{array}$ \\
\hline
\end{tabular}




\begin{tabular}{|c|c|c|c|c|c|}
\hline $\begin{array}{l}\text { Delia Owens: } \\
\text { Djevojka iz močvare }\end{array}$ & $x$ & & & $x$ & $x$ \\
\hline $\begin{array}{l}\text { Elena Ferrante: } \\
\text { Lažljivi život odraslih }\end{array}$ & & $x$ & $X$ & & $X$ \\
\hline $\begin{array}{l}\text { Elif Shafak: } \\
\text { Kako sačuvati mentalno } \\
\text { zdravlje u doba podjela }\end{array}$ & $x$ & & $x$ & $x$ & \\
\hline $\begin{array}{l}\text { Lisa Genova: } \\
\text { Još uvijek Alice }\end{array}$ & $x$ & $x$ & & & $X$ \\
\hline $\begin{array}{l}\text { Maja Lunde: } \\
\text { Snježna sestra }\end{array}$ & $x$ & & $X$ & $x$ & \\
\hline $\begin{array}{l}\text { Margaret Atwood: } \\
\text { Vražji okot }\end{array}$ & & $x$ & & $x$ & $x$ \\
\hline $\begin{array}{l}\text { Oyinkan Braithwaite: } \\
\text { Moja sestra: serijski } \\
\text { ubojica }\end{array}$ & $x$ & & $X$ & $x$ & \\
\hline $\begin{array}{l}\text { Anna Burns: } \\
\text { Mljekar }\end{array}$ & $x$ & & & & $\mathrm{X}$ \\
\hline $\begin{array}{l}\text { Bernardine Evaristo: } \\
\text { Djevojka: žena: drugo }\end{array}$ & $x$ & & $X$ & & \\
\hline $\begin{array}{l}\text { Darko Cvijetić: } \\
\text { Schindlerov lift }\end{array}$ & & $x$ & & $x$ & \\
\hline $\begin{array}{l}\text { David Foenkinos: } \\
\text { Misteriozni Henri Pick }\end{array}$ & & $x$ & & $x$ & \\
\hline $\begin{array}{l}\text { Elif Shafak: } \\
\text { Tri Evine kćeri }\end{array}$ & & $x$ & & $x$ & \\
\hline $\begin{array}{l}\text { Etgar Keret: } \\
\text { Kvar na rubu galaksije }\end{array}$ & & $\mathrm{X}$ & & & $\mathrm{X}$ \\
\hline $\begin{array}{l}\text { Golnaz Hashemzadeh } \\
\text { Bonde: } \\
\text { To smo bili mi }\end{array}$ & & & $X$ & & $X$ \\
\hline $\begin{array}{l}\text { Isabel Allende: } \\
\text { Japanski ljubavnik }\end{array}$ & & $x$ & & $\mathrm{X}$ & \\
\hline $\begin{array}{l}\text { Kazuo Ishiguro: } \\
\text { Blijed pogled na bregove }\end{array}$ & & $x$ & & & $X$ \\
\hline $\begin{array}{l}\text { Nebojša Lujanović: } \\
\text { Maratonac }\end{array}$ & & $x$ & & & $x$ \\
\hline $\begin{array}{l}\text { Ocean Vuong: } \\
\text { Na zemlji smo nakratko } \\
\text { predivni }\end{array}$ & $x$ & & & $\mathrm{X}$ & \\
\hline $\begin{array}{l}\text { Velibor Čolić: } \\
\text { Egzil za početnike }\end{array}$ & & $x$ & & $x$ & \\
\hline
\end{tabular}

Naslov koji se posebno ističe u tablici 1. jest triler Nijema pacijentica Alex Michaelides, najčešće recenziran naslov u odabranim korpusima. Elif Shafak jedina je autorica čija su dva naslova zastupljena u oba korpusa. 
Što se tiče isključivo autora, među blogericama može se uočiti značajnije podudaranje recenziranih pisaca. U minimalno dva bloga pojavljuje se čak 90 autora, a u sva tri 25 autora. $S$ druge strane, u oba potkorpusa korpusa P ponavljaju se 23 imena. Slika 1. prikazuje liste autora koji se pojavljuju u sva tri bloga, u oba potkorpusa profesionalnih tekstova te izdvaja jedinu autoricu spomenutu u svih pet potkorpusa: Margaret Atwood. Kao što je vidljivo u tablici 1., Vražji okot Margaret Atwood recenziran je u potkorpusima B, D i E. Ostali recenzirani naslovi ove spisateljice jesu Sluškinjina priča u potkorpusima A i C, Alias Grace u B i Svjedočanstva u C. Široka zastupljenost ove autorice u oba korpusa zapravo samo potvrđuje činjenicu da je riječ o književnici koja je istovremeno cijenjena u književnoteorijskim i akademskim krugovima ${ }^{[2]}$ i popularna među publikom ${ }^{[3]}$ Pri pogledu na sliku 1. uočljiva je veća prisutnost hrvatskih autora u korpusu $\mathrm{P}$ te njihova gotovo potpuna odsutnost u korpusu N (uz 3 iznimke). Vezano uz rodnu statistiku, u korpusu N od 25 navedenih književnika 15 je žena, dok je u korpusu P omjer autorica i autora deset

4. 


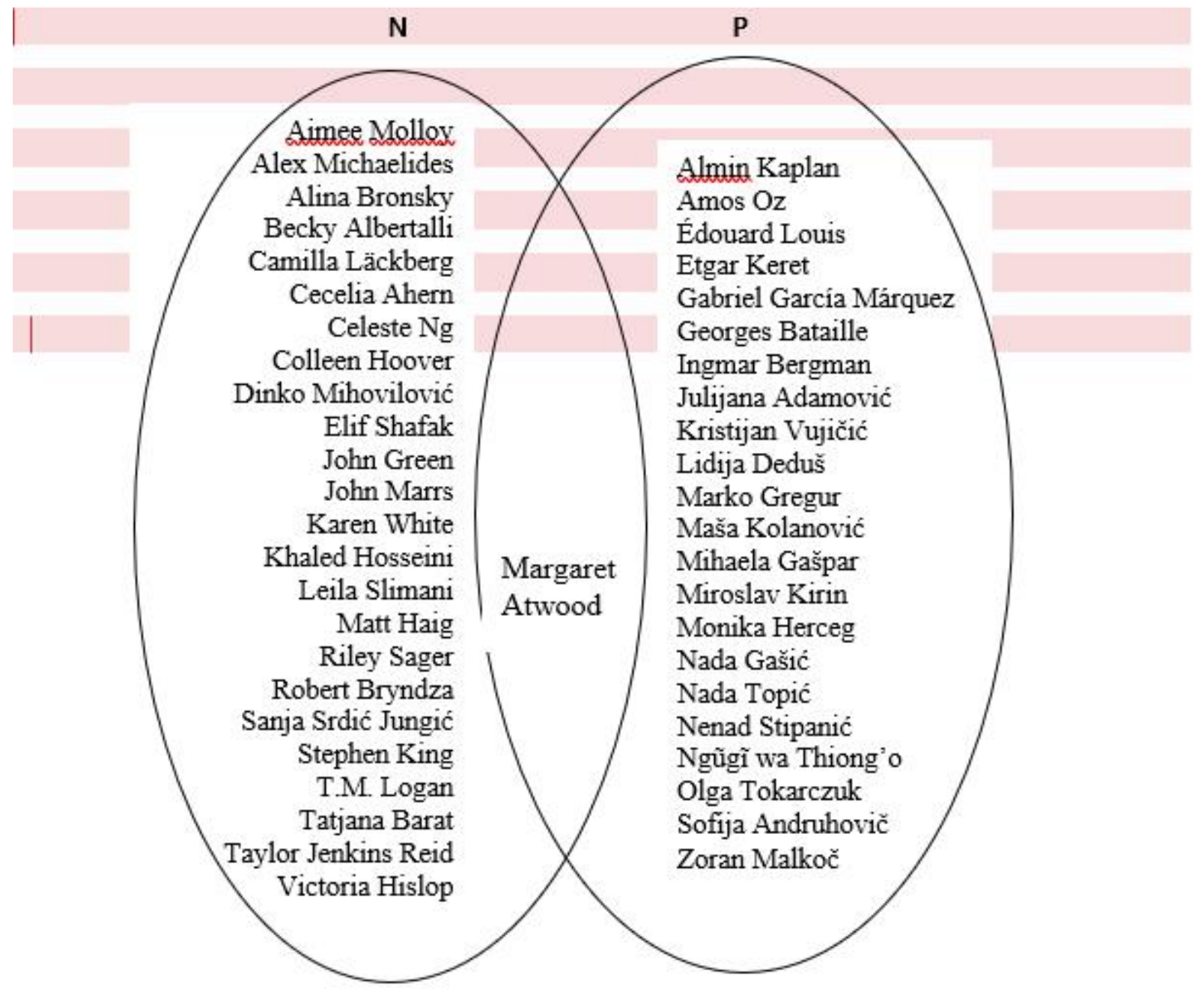

Slika 1 - Lista autora koji se pojavljuju u sva tri bloga (N) te onih koji se pojavljuju u oba potkorpusa profesionalnih tekstova $(\mathrm{P})$. Margaret Atwood jedina se pojavljuje u svih pet potkorpusa.

Analiza najčešćih riječi

Dva korpusa generirana u programu Sketch Engine kao tekstualni dokumenti prebačena su u program MAXQDA 2020, koji omogućuje vizualni prikaz najčešćih riječi u korpusu te mogućnost kreiranja liste zaustavnica (Stop List), odnosno riječi koje se mogu izuzeti iz vizualnog prikaza. U ovom slučaju na listu su, prema nahođenju istraživačice, dodane čestice, veznici te morfološke varijante istih riječi (jer MAXQDA ne prepoznaje specifičnosti hrvatskog jezika).

Slike 2. i 3. prikazuju učestalost pojedinih riječi u korpusu $\mathrm{N}$ odnosno $\mathrm{P}$. $U$ oba korpusa ističu se riječi poput „knjiga”, „roman”, „život”, „priča”; međutim, moguće je uočiti i određene specifičnosti svakog korpusa. Očekivano, korpus neprofesionalnih čitateljica odlikuje veća neformalnost u izrazu, što se ogleda u upotrebi emotikona u tekstu te korištenju prvog lica jednine (i množine): 
„nisam”, „pratimo”, „mene”, „moj” i slično. Mnoge riječi sugeriraju orijentaciju prema zapletu: „tema”, „likovi”, „radnja”, „tajne”. S druge strane, u korpusu P može se primijetiti veći broj riječi koje se odnose na poeziju: „pjesma”, „poezija”, „zbirka”, „pjesnikinja”. Navedeno ne iznenađuje, budući da Vijenac godinama redovito promovira poeziju putem rubrike Republika stiha Krešimira Bagića. Zanimljivo je primijetiti zastupljenost riječi vezanih uz obiteljske odnose u oba korpusa, a osobito u korpusu N: „majka”, „kćeri”, „otac”, „supruga”, „obitelj”. Pri analizi najčešćih sintagmi korpusa N izraz „obiteljska drama” iskristalizirao se kao jedan od najčešćih. Budući da je karakteristika korpusa $\mathrm{N}$ bila i veća zastupljenost romana, može se zaključiti da su blogeri kao naslove za recenziju češće birali romane koji se bave obiteljskim odnosima, što je svakako jedna od arhetipskih književnih tema. Sljedeći korak, analiza najčešćih sintagmi, omogućit će dodatnu kontekstualizaciju ovih općenitih smjernica korpusa koje su sugerirale najčešće riječi.

5.

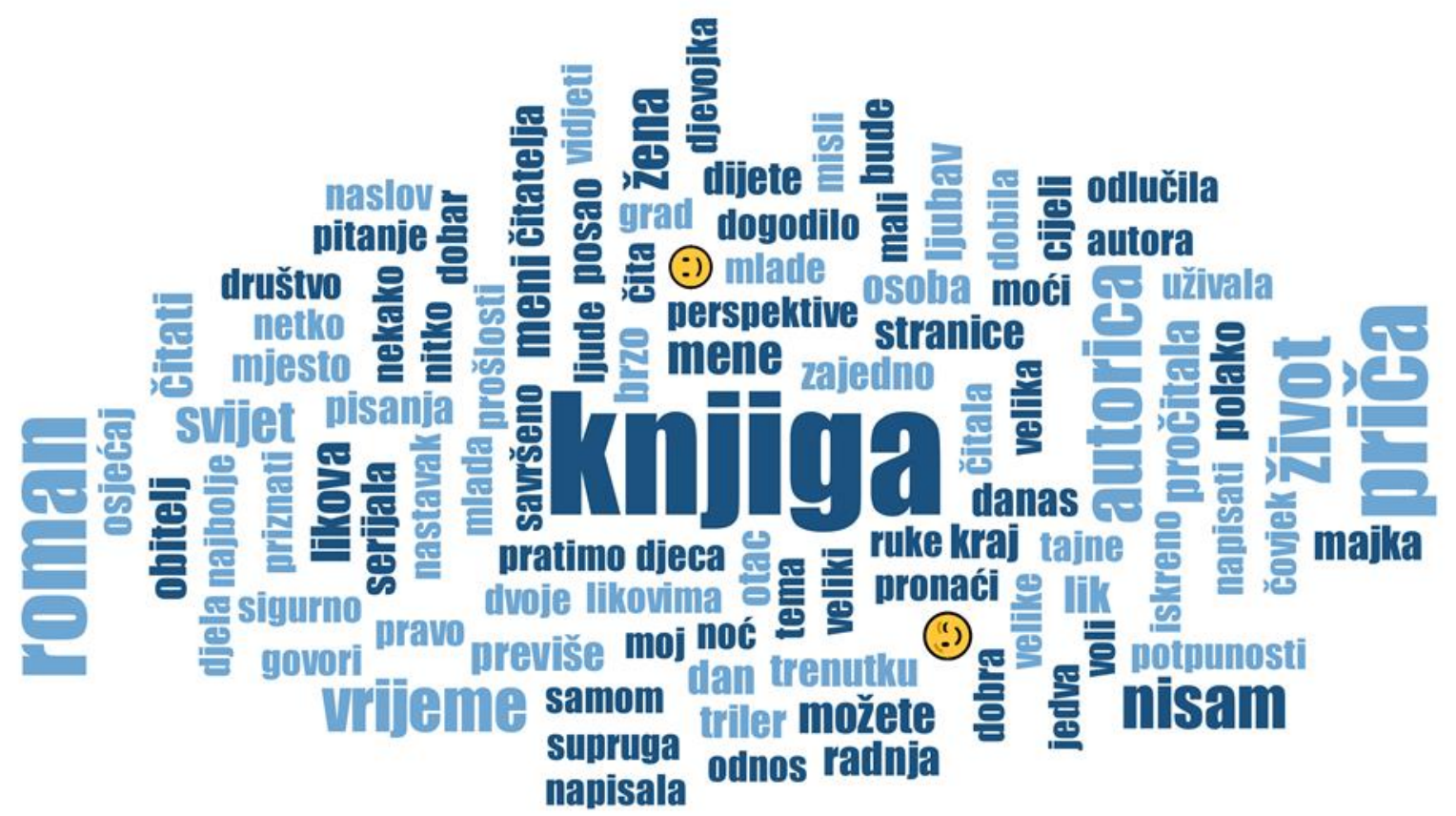

Slika 2 - Najčešće riječi u korpusu N prema oblaku riječi 


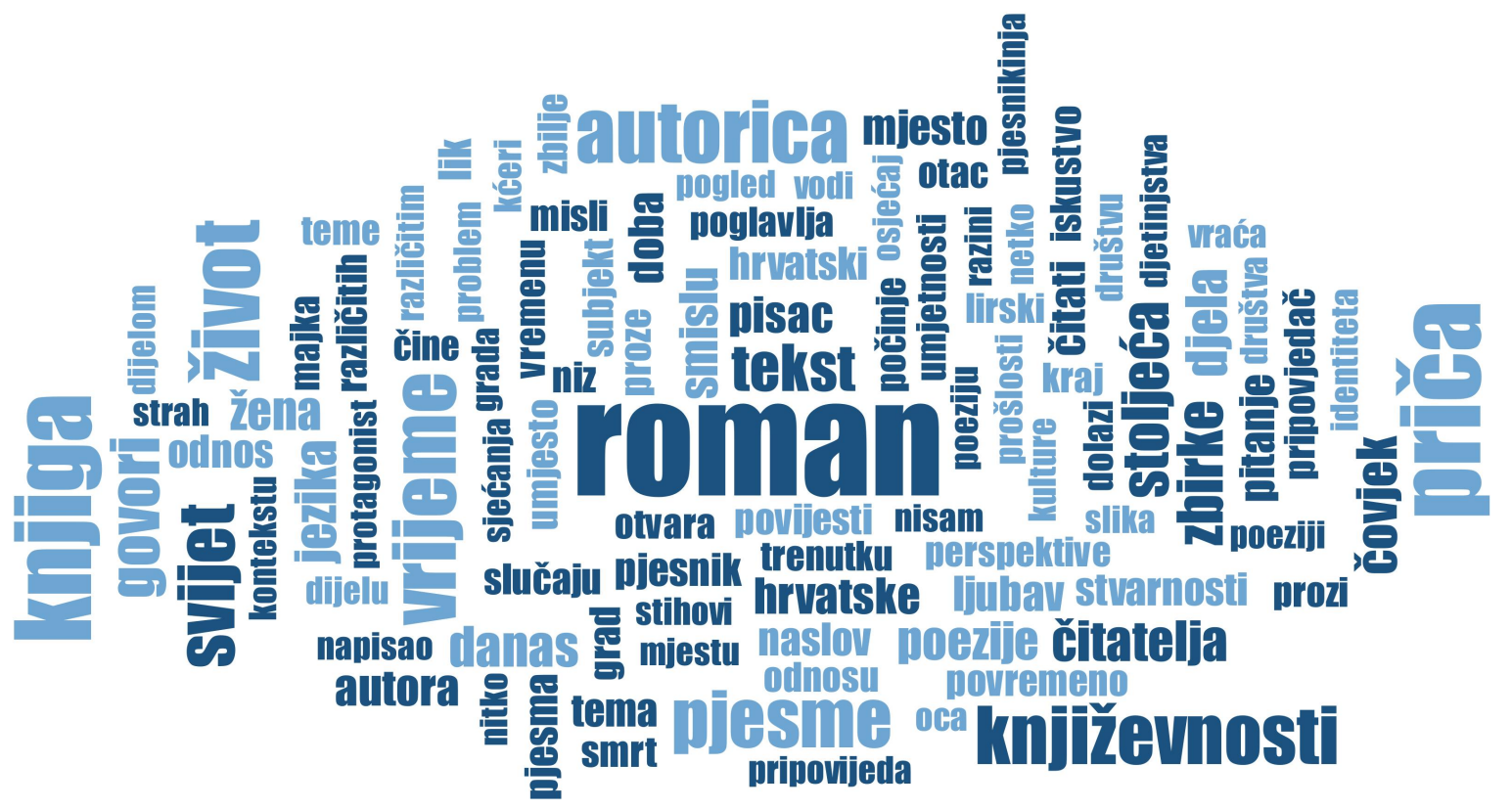

Slika 3 - Najčešće riječi u korpusu P prema oblaku riječi

Analiza najčešćih sintagmi

Na korpusu $\mathrm{N}$ te na korpusu $\mathrm{P}$ provedene su analize najčešćih sintagmi (Multi-word Terms) $\mathrm{u}$ odnosu na korpus hrvatskog jezika u Sketch Engineu. Prvih 50 sintagmi svakog korpusa detaljno je pomoću navedenog programa pregledano u svim kontekstima u kojima se pojavljuju.

Primijećeno je da su mnoge najčešće sintagme zapravo naslovi djela koji se pojavljuju na različitim mjestima u tekstu i njegovoj opremi ili standardizirani izrazi koje su autorice uključile u svaku svoju recenziju (npr. „naslov izvornika”). Nakon što su takve sintagme uklonjene, dobivena je tablica 2., koja sadrži 20 najčešćih sintagmi svakog korpusa, poredanih od najčešćih (gornji lijevi kut) prema manje učestalima (donji desni kut), za svaki korpus zasebno.

Provjerom konteksta utvrđena su i točna značenja sintagmi te se one okvirno, za potrebe ove analize, mogu podijeliti u sedam kategorija: duljina i dijelovi teksta, pojmovi koji sugeriraju žanr, pojmovi književne analize, bibliografija autora, serijalnost, hrvatska književnost $\mathrm{i}$ iskustvo čitanja.

Provjerom u kontekstima ustanovljeno je da se, na primjer, „novi roman”, „nova zbirka”, „debitantski roman" pojavljuju gotovo isključivo uz ime autora, odnosno služe smještanju djela u bibliografiju određenog pisca. Bourrier i Thelwall primijetili su važnost koju čitatelji pridaju imenu autora pri odabiru sljedećeg djela za čitanje, odnosno recenziju. U nastavku će se izdvojiti nekoliko sintagmi koje zahtijevaju određenu kontekstualizaciju. 
„Krenuti s čitanjem” sintagma je koja se pojavljuje u N korpusu u različitim varijantama, odnosno u prvom licu jednine ili drugom množine. Služi opisu osobnog, empirijskog iskustva čitanja: „kad jednom krenete s čitanjem nećete ni osjetiti da imate u rukama knjigu tolikog obima”, „čim sam krenula s čitanjem Queenie mi se svidjela”, „kad sam krenula s čitanjem jednostavno nisam mogla stati”, „nemoguće je krenuti s čitanjem i zaustaviti se” itd. Također, sugerira važnost početka knjige, odnosno početka iskustva čitanja.

Nadalje, uočeno je kako se sintagma „prethodna knjiga” u većini primjera odnosi na prethodnu knjigu u serijalu, a u manje slučajeva na prethodnu knjigu određenog autora, zbog čega je uvrštena u kategoriju serijala. „Novi roman” najčešće stoji uz ime autora, ali u nekoliko slučajeva odnosi se na novi roman određenog serijala (iako je teško razgraničiti kategorije, budući da se primjeri odnose na serijale čije je sve nastavke napisao isti autor).

Neočekivana je po učestalosti sintagma „tristotinjak stranica”. Ona se pojavljuje u dva potkorpusa, Čitateljica i Books\&Sweets, kao mjerilo za kratak roman odnosno za idealnu duljinu romana: „pred nas je postavila neveliku knjigu sa svega tristotinjak stranica”, „knjiga ima svega tristotinjak stranica što je po meni idealna duljina romana”, „sjajno ga je upakirala u roman od skromnih tristotinjak stranica na čemu joj aplaudiram jer nema praznog hoda" i slično.

Primijećeno je da se kategorije oba korpusa u velikoj mjeri preklapaju, uz iznimku kategorija serijala te iskustva čitanja (elementi osobnog iskustva bili su vidljivi i pri analizi riječi), koje su svojstvene N korpusu te kategorija književne analize i hrvatske književnosti - na kojoj inzistira korpus $\mathrm{P}$ (a što je bilo naznačeno i u popisu naslova i autora).

Pianzola, Rebora i Lauer također su primijetili da serijalnost, odnosno objavljivanje romana u dijelovima ili nastavcima utječe na povećan angažman odnosno broj komentara (uglavnom neprofesionalnih) čitatelja na digitalnoj platformi Wattpad.

Iskustvo čitanja kao važan element govora o književnosti u neprofesionalnih književnih blogova uočila je i Steiner jer su blogeri često opisivali okolnosti čitanja te sam fizički susret s knjigom (kupovina, vanjski izgled, dodirivanje, miris) (487). Slično je zapazio i Škopljanac pri istraživanju prisjećanja na književni tekst neprofesionalnih čitatelja: spominjanje određenih emocija pri prisjećanju na tekst često je bilo vezano uz okolnosti čitanja, odnosno prirodnu okolinu ili načine na 
koji su ispitanici došli do knjige (245). U istom istraživanju uočen je i značaj koji su ispitanici davali početku i kraju knjige (kao i u tablici 2.), što se može pripisati psihološkom efektu prvenstva (Škopljanac 247).

Žanr je jedna od najzastupljenijih kategorija u oba korpusa, a druga istraživanja već su potvrdila važnost ove kategorije za neprofesionalne čitatelje, digitalno okruženje i cjelokupnu književnu industriju. Pianzola, Rebora i Lauer uočili su kako korisnici platforme Wattpad pridaju veliko značenje žanru, odnosno ta kategorija značajno utječe na njihovo ponašanje na platformi. Walsh i Antoniak pisale su o važnosti i komercijalnom potencijalu koju online kategoriziranje po (vrlo široko shvaćenim) književnim žanrovima, a koje vrše čitatelji korisnici stranice Goodreads, ima za kompanije poput Amazona te za nakladničke i ostale kreativne industrije, čiji interesi često dovode i do etički upitnih načina prikupljanja podataka.Tablica 2. - Najčešće sintagme u oba korpusa, podijeljene u okvirne kategorije

6.

\begin{tabular}{|l|l|l|l|l|}
\hline P & pjesma u prozi & $\begin{array}{l}\text { protagonist } \\
\text { romana }\end{array}$ & nov roman & stvarnosna poezija \\
\hline lirski subjekt & kratka priča & naslov romana & nova zbirka & knjiga pjesama \\
\hline dio romana & $\begin{array}{l}\text { početak } \\
\text { romana }\end{array}$ & povijesni roman & zbirka priča & $\begin{array}{l}\text { hrvatska } \\
\text { književnost }\end{array}$ \\
\hline glavni junak & $\begin{array}{l}\text { hrvatsko } \\
\text { pjesništvo }\end{array}$ & $\begin{array}{l}\text { pripovjedač } \\
\text { romana }\end{array}$ & književni tekst & kratka proza \\
\hline N & \multicolumn{5}{|l|}{} \\
\hline psihološki triler & $\begin{array}{l}\text { debitantski } \\
\text { roman }\end{array}$ & ljubavni roman & stil pisanja & kraj knjige \\
\hline cijela knjiga & $\begin{array}{l}\text { posljednja } \\
\text { stranica }\end{array}$ & roman autorice & brzo čita & roman iz serijala \\
\hline knjiga iz serijala & krenuti s čitanjem & obiteljska drama & ljubavna priča & prethodna knjiga \\
\hline $\begin{array}{l}\text { tristotinjak } \\
\text { stranica }\end{array}$ & dio knjige & cijeli roman & novi roman & dio serijala \\
\hline
\end{tabular}

DUUINA I DUELOVI TEKSTA ŽANR POJMOVI KNIŽZEVNE ANALIZE

BIBUOGRAFUA AUTORA SERIJAL HRVATSKA KNIŽEVNOST 


\section{Analiza primjera}

Na temelju analize naslova i autora recenziranih u oba korpusa za pomno čitanje odabrane su sve recenzije knjige Nijema pacijentica Alexa Michaelidesa, kao najčešće recenziranog naslova, te naslova Vražji okot Margaret Atwood, jedine spisateljice zastupljene u svih pet potkorpusa. Budući da je Nijema pacijentica recenzirana u sva tri književna bloga te jednom profesionalnom potkorpusu, a Vražji okot u oba P potkorpusa te u jednom blogu, ukupno će se uzeti u obzir sedam tekstova, četiri iz korpusa $\mathrm{N}$ i tri iz $\mathrm{P}$.

Prijašnja istraživanja koja su digitalnim putem analizirala učestalost riječi povezanih s osjećajima u online amaterskim književnim recenzijama pokazala su kako su neke od glavnih odlika online čitateljskih komentara intimnost te izražavanje emocija (Pianzola, Rebora i Lauer), što je uočljivo i pri čitanju recenzija sva tri književna bloga. Gotovo čitavi tekstovi pisani su u prvom licu, u ispovjednom tonu. Vrlo često povezuju pročitani tekst s iskustvima iz osobnog života: „Ne znam da li ste ikad imali prilike surađivati s nekim kazališnim redateljem, ali ja jesam, i ne mogu vam opisati koliko ih je Atwood dobro opisala u liku Felixa” (Jembrek, Vražji okot); „Pod utjecajem čitanja čak sam se bacila i na malo istraživanje grčke mitologije pod čijim utjecajem ja autor odrastao na Cipru” (Kovačević). Također, lako je uočiti i spominjanje različitih emocija pri opisivanju radnje: „... kad shvatiš da si skoro cijelo vrijeme čitanja bio u krivu i da ti je nešto prošlo ispod radara ne naljutiš se, nego samo poželiš zapljeskati autoru što je na jedan fini način izveo trik pred tvojim očima” (Kovačević); „Dirnula me do suza. Nasmijala. Mentalno i duševno stimulirala” (Jembrek, Vražji okot); „Preplavili su me tuga, šok, ali i ushit i zadovoljstvo. Baš onakav miks osjećaja koji i tražim prilikom čitanja psihološkog trilera" (Jembrek, Nijema pacijentica).

Kao što je vidljivo i iz kvantitativne analize, na blogovima je određen prostor posvećen samom iskustvu čitanja knjige: „Stoga me iznenadilo kad me je Nijema pacijentica uhvatila već od prve stranice” (Jembrek, Nijema pacijentica); „Neizmjerno sam uživala čitajući, stranice su nestajale u trenu, morala sam znati zašto” (Kovačević); „Nijemu pacijenticu, triler od nevelikih tristo stranica pročitala sam u jednoj večeri, jer spustiti knjigu nije dolazilo u obzir” („Alex Michaelides: Nijema pacijentica“). Zanimljivo, slična izjava u prvom licu o vlastitom iskustvu čitanja romana Nijema pacijentica nalazi se i u prvom odlomku teksta kritike u Vijencu: „Roman Nijema pacijentica dug 
tristotinjak stranica toliko je napet da sam ga pročitala u dahu i odlučila ga preporučiti izbirljivim čitateljima Vijenca” (Muhoberac, „Napet psihijatrijski triler”). Rečenica u prvom licu pojavljuje se i u recenziji Vražjeg okota: „Kad sam prije nekoliko mjeseci prvi put pročitala knjigu Margaret Atwood, nastalu prema narudžbi izdavačke kuće Random House (...) ni sanjala nisam što će nam se sve dogoditi do ovoga, drugoga čitanja” (Muhoberac, „Olujin otok, zlobni okot”). Međutim, važno je napomenuti kako je prvo lice u ovim tekstovima ograničeno na tek pokoju rečenicu, za razliku od ispovjednog tona koji prevladava u cjelokupnim tekstovima blogova. Uočljive su i velike stilske razlike između tekstova koji pripadaju različitim korpusima. Blogove odlikuje neformalnost u izrazu („Mene je zaista lako kupiti obećanjem o dobrom trileru, iako bi s godinama trebala biti pametnija, jer nakon stotina pročitanih, možda je njih desetak bilo baš ono WOW” (,Alex Michaelides: Nijema pacijentica“), povremeno se pojavljuju pravopisne pogreške ili ponešto nezgrapne rečenice. $U$ svakom slučaju, vidljivo je da tekstovi nisu uređivani, što je jedna od spomenutih kritika van der Weela upućena internetskim sadržajima koje kreiraju korisnici. Osim toga, dok u blogovima prevladavaju općeniti dojmovi o radnji, sve tri profesionalne recenzije odlikuje posvećenost detaljima te korištenje stručnih pojmova iz književne analize:

... Vražji okot. Oluja ispričana isponova, već naslovnom sintagmom s lucidnom premetaljkom okot - otok, i asocijacijom na Krležino djelo kao i na Shakespeareov začarani otok u čarobnjačkoj drami Oluji, te podnaslovnim izrazom isponova, upućujući na ludističan otklon od standardnoga ... Dvije stotine i osamdeset stranica umrežava petočinu, po uzoru na dramske tekstove, ali proznu teksturu, s Prologom i Epilogom koji datumski predočuju Globe-strukturu svijeta kao zrcala kazališta i otoka: 13. ožujka 2013. i 31. ožujka 2013. (Muhoberac, „Olujin otok, zlobni okot”)

Radi se ovdje dakle o Oluji u Oluji u Oluji. Pri tome nije sasvim točno sve "oluje” iz prethodne rečenice staviti u kurziv; neke su od njih posve stvarne, vremenske oluje, neke su metaforičke, a neke su drame. Ključno je što su baš sve na ovaj ili onaj način vezane uz onu Shakespeareovu. $U$ tom je smislu „Vražji okot” pravi i upravo sjajni primjer tzv. postmodernističkog prepisivanja. (Solar)

Osim stilskih finesa te posvećenosti detaljima, kvantitativnom analizom nije bilo moguće zahvatiti još jednu karakteristiku ovdje analiziranih tekstova profesionalnih kritičara, osobito Vijenca, a to je povezivanje analiziranog djela s drugim književnim djelima i kulturnim pojavama. „Taj je obrat povezan i s mogućim konotacijama uz Carrollovu Alicu iza zrcala, koja otkriva drukčiji svijet iluzije i 
stvarnosti. Da bismo uživajući u čitanju Nijeme pacijentice izbjegli konzekvencije percepcije slike (ujedno i krimi-zapleta) kakvu nudi npr. Gibsonova teorija prirodne percepcije i njegov nominalizam (...)” (Muhoberac, „Napet psihijatrijski triler”), „Postavljanje zatvorske Oluje nerijetko je duhovito i ironično, prepuno anegdota, a podsjetilo me i na Brešanovu grotesku Predstava Hamleta u selu Mrduša Donja” (Muhoberac, „Olujin otok, zlobni okot”).

Međutim, iako se može govoriti o određenim tipičnim obilježjima, važno je ne generalizirati analizirane recenzije, budući da svaku odlikuje individualan stil i autorski pristup. Tako, primjerice, blog Knjige su moj svijet recenzije često obogaćuje i potkrepljuje odgovarajućim citatima iz djela, iako je vraćanje na sam književni tekst karakterističnije za profesionalne kritičare (Škopljanac 243). Još jedna mogućnost koju blogovi imaju jest dijalog i interakcija s vlastitom publikom. Moguće je ostavljati komentare, a neki blogeri i izravno postave pitanje na koje publika može odgovoriti u komentarima: „p.s. Koliko bi vas razveselila informacija da je film po romanu u planu? Onako od 1 do 10?” („Alex Michaelides: Nijema pacijentica”).

Također, treba uzeti u obzir i da mnogi blogeri ostvaruju ili žele ostvariti određenu suradnju s nakladnicima, što često i otvoreno daju do znanja. Nekad je komercijalni aspekt više, a nekad manje eksplicitno naveden na takvim blogovima. Primjerice, određene recenzije bloga Knjige su moj svijet završavaju pozivom na kupnju knjige, odnosno linkom koji vodi na internetsku trgovinu. Ovaj položaj između, s jedne strane, potencijala za povećanje demokratičnosti u razgovoru o književnosti, te opasnosti komercijalne eksploatacije s druge strane, karakterističan je za mnoge suvremene internetske platforme i društvene mreže (Walsh i Antoniak).

\section{Zaključak}

Književni blogovi profilirali su se kao važan dio nakladničke industrije, što znači da ih, uz aspekt demokratizacije govora o književnosti, odlikuje i određeni komercijalni potencijal. Ovdje prikazano istraživanje analiziralo je relativno male korpuse neprofesionalnih književnih blogova i profesionalnih književnih recenzija u Hrvatskoj, te je potvrdilo neka saznanja iz prethodnih istraživanja obilježja govora o književnosti neprofesionalnih čitatelja i autora književnih blogova. Neke karakteristike književnih blogova koje su uočene proizlaze iz samog formata. To su 
ispovjedni, dnevnički ton koji podrazumijeva pisanje o književnosti u prvom licu, povezivanje djela s događajima iz osobnog života, odnosno objavljivanje sadržaja obično vezanog uz privatnu sferu, pozivanje publike na interakciju u komentarima te neuređeni sadržaj, budući da blogove obično piše jedna osoba i podrazumijevaju relativno brzu proizvodnju stalno novih tekstova. Autorice blogova u ovom istraživanju redovito su pisale i o samom iskustvu i okolnostima čitanja knjiga.

Pri kvantitativnoj usporedbi s korpusom profesionalnih književnih kritičara uočena je značajna razlika u odabiru autora i naslova za recenzije. Književni blogovi pišu o popularnoj književnosti i žanrovima za koje u profesionalnoj kritici često nema mjesta, što pokazuje i česta pojava sintagmi vezanih uz književne serijale i romane u nastavcima u korpusu neprofesionalnih čitatelja ovog istraživanja. S druge strane, profesionalni kritičari njeguju žanrove često zanemarene od strane šire javnosti, kao što su poezija i domaća književnost. U ovom istraživanju, neprofesionalni blogovi pokazali su sklonost stranim, ženskim autoricama, a profesionalni tekstovi imali su veću zastupljenost domaćih, muških, autora. U tom smislu dva korpusa se, na neki način, nadopunjuju. Međutim, postoje autori koji su značajno zastupljeni i u neprofesionalnih i u profesionalnih čitatelja, a u ovom slučaju pokazalo se da je to Margaret Atwood, jedina autorica čija su se djela pojavila u svim potkorpusima.

Istraživanje na različitim razinama potvrdilo je kako se određeni fenomeni uočavaju samo iz određenih perspektiva. Analiza primjera iz odabranih tekstova potvrdila je neka saznanja kvantitativne analize (osobni, neformalni izraz te opis iskustva čitanja u književnih blogova, korištenje stručnih pojmova profesionalnih kritičara), ali i otkrilo nijanse između pojedinih tekstova. Pokazalo se kako i profesionalni kritičari ponekad posežu za prvim licem i opisuju vlastito iskustvo čitanja, kao što se pokazalo i da povezuju književna djela s drugim književnim djelima i kulturnim pojavama te da posvećuju veliku pozornost detaljima u tekstu, iako i blogeri ponekad svoje navode potkrepljuju citatima iz književnog teksta, odnosno oslanjaju se na njega pri analizi. Makroanalizom je moguće uočiti određene zajedničke karakteristike i tendencije svakog korpusa, međutim, analiza primjera otkriva neke suptilne sličnosti između tekstova različitih korpusa, kao i karakteristike svakog pojedinog teksta iza kojeg stoji individualni autor. 


\section{Bibliografija}

„Alex Michaelides: Nijema pacijentica." Čitateljica, 6. listopada 2019., www.citateljicablog.wordpress.com/2019/10/06/alex-michaelides-nijema-pacijentica/. Pristupljeno 12. srpnja 2021.

Bourrier, Karen i Mike Thelwall. „The Social Lives of Books: Reading Victorian Literature on Goodreads." Journal of Cultural Analytics, vol. 5, no. 1, 2020, culturalanalytics.org/article/12049the-social-lives-of-books-reading-victorian-literature-on-goodreads. Pristupljeno 15. prosinca 2021. Horvat, Jasna, et al. „Književna kritika, nakladničke i knjižničarske anotacije u modernim i tradicionalnim medijima." Arhivi, knjižnice, muzeji, br. 17, 2014, pp. 72-93.

Jembrek, Ana. „Nijema pacijentica - Alex Michaelides.” Knjige su moj svijet, 15. listopada 2019., www.knjigesumojsvijet.com/2019/10/15/nijema-pacijentica-alex-michaelides/. Pristupljeno 12. srpnja 2021.

Jembrek, Ana. „Vražji okot - Margaret Atwood.” Knjige su moj svijet, 4. kolovoza 2019., www.knjigesumojsvijet.com/2019/08/04/vrazji-okot-margaret-atwood/. Pristupljeno 12. srpnja 2021. Kovačević, Dijana. „Nijema pacijentica - Alex Michaelides.” Books\&Sweets, 24. listopada 2019., www.bookssweets.wordpress.com/2019/10/24/nijema-pacijentica-alex-michaelides/. Pristup 12. srpnja 2021.

Muhoberac, Mira. „Napet psihijatrijski triler.” Vijenac, www.matica.hr/vijenac/697/napetpsihijatrijski-triler-30948/. Pristupljeno 12. srpnja 2021.

Muhoberac, Mira. „Olujin otok, zlobni okot.” Vijenac, www.matica.hr/vijenac/683/olujin-otok-zlobniokot-30349/. Pristupljeno 12. srpnja 2021.

Olujić, Kristina. „Stoljeće i pol Vijenca, časopisa koji je počeo tiskati hrvatsku riječ.” Nacional, 15. lipnja 2019, www.nacional.hr/stoljece-i-pol-vijenca-casopisa-koji-je-poceo-tiskati-hrvatsku-rijec/. Pristupljeno 7. lipnja 2021.

Pianzola, Federico, Simone Rebora, i Gerhard Lauer. „Wattpad as a Resource for Literary Studies. 
Quantitative and Qualitative Examples of the Importance of Digital Social Reading and Readers' Comments in the Margins." PLoS ONE, vol. 15, no. 1, 2020, doi: 10.1371/journal.pone.0226708.

Solar, Vesna. „Margaret Atwood: Vražji okot.” Moderna vremena info, 7. kolovoza 2019., www.mvinfo.hr/clanak/margaret-atwood-vrazji-okot. Pristupljeno 20. svibnja 2021.

Steiner, Ann. „Personal Readings and Public Texts: Book Blogs and Online Writing about Literature." Culture Unbound: Journal of Current Cultural Research, vol. 2, no. 4, 2010, pp. 471-94. Škopljanac, Lovro. Književnost kao prisjećanje: što pamte čitatelji. Naklada Ljevak, 2014. Van der Weel, Adriaan. „Literary Authorship in the Digital Age.” The Cambridge Handbook of Literary Autorship, uredili Ingo Berensmeyer, Gert Buelens i Marysa Demoor, Cambridge University Press, 2020, pp. 218-34.

Walsh, Melanie i Maria Antoniak. „The Goodreads 'Classics': A Computational Study of Readers, Amazon, and Crowdsourced Amateur Criticism." Post45 x Journal of Cultural Analytics, no. 7, 2021, post45.org/2021/04/the-goodreads-classics-a-computational-study-of-readers-amazon-andcrowdsourced-amateur-criticism/. Pristupljeno 15. prosinca 2021. 
[1] Za razliku od odabranih blogova, koji postoje od 2018. godine, prvi digitalizirani broj Vijenca (broj 134) iz 1999. je godine, dok rubrika Kritike na stranici mvinfo.hr seže u 2006. godinu.

[2] Prema stranici opensyllabus.org, koja prikuplja podatke o silabusima iz 140 zemalja, Margaret Atwood spominje se 5.920 puta. Radi usporedbe, Tolstoj se pojavljuje 6.065 puta.

[3] Nalazi se u kategoriji „Klasika” na najvećoj internetskoj društvenoj platformi neprofesionalnih čitatelja - Goodreads (Walsh i Antoniak).

\section{c) (i) (9)}

Creative Commons Attribution-NonCommercial-NoDerivatives 4.0 International License 